\title{
Performance Improvement Strategy with SWOT Analysis for Anutapura Hospitals at Palu City, Central Sulawesi
}

\author{
Husnah \\ Department of Management, Faculty of Economics, Tadulako University, Palu, Central Sulawesi, Indonesia
}

\begin{abstract}
This study purpose is to determine strategies to develop hospital performance based on identification of strengths, weaknesses, opportunities and threats in internal and external environment of hospital. Research location is Anutapura Hospital at Palu City. The study was conducted from February to June 2018. The data was collected by observation, focus group discussion (FGD), and interviews. The analysis used was descriptive analysis method and SWOT analysis.The study results found four strategies to develop hospital performance. First is SO Strategy to improve HR competencies, to encourage hospital service production through Bed Occupancy Ratio (BOR) optimization by improving work culture in accordance with SOP of "Excellent Service Image " with Motto of "Smile and Friendly " in hospital environment, expanding the marketing network through verbal and non-verbal promotion with community socioculture approach, and optimizing outpatient services ( 20 polyclinics), medical support installations (10 installations), and non-medical support installations (5 installations). Second is WO Strategy to utilize Public Service Agency (PSA) revenues to improve HR competencies and medical and nonmedic facilities and insights, promotion and expanding cooperation with other insurance and improve service socialization through work culture approaches to minimize complaints of dissatisfaction from public Hospital service users. Third is ST Strategy to encourage hospitals to improve HR competencies, increase renewable technology, and socializing excellent services to anticipate competition from other hospitals, increasing cooperation with government to develop general health in hospitals through an programmed and sustainable R \& $\mathrm{D}$ approach and strives for vertical development, utilizing the other functions of old buildings and looking for new land for long-term development, considering the need for health services continuity to anticipate more population when development area is narrower. Forth is WT strategy to promote human resources, especially cardiac and surgical specialists, optimizing collaboration with government in specialist medical education assistance, optimizing marketing channels and socializing the prime service culture to anticipate new competitor threats and increasing land usage through improvement of medical facilities and infrastructure and non-medical.
\end{abstract}

Keywords: Strategy, SWOT, Performance, Hospital.

DOI: $10.7176 / \mathrm{JRDM} / 52-03$

\section{INTRODUCTION}

The company's long-term performance is obtained if the company has a strategy as the main element for its managerial decisions (Wheelen and Hunger, 2003: 4). Performance as a company goal is divided into two, namely financial performance and non-financial performance. David (2010:24) reveals that businesses that use various strategic management concepts show a significant improvement in financial performance compared to companies without systematic strategic planning activities. Wernefelt (1984) and Barney (1991) stated that companies can achieve competitive advantage by utilizing unique resources and strategies. Panrell (2006) showed a "businessstrategy-performance" relationship. The substance of his thinking was the competitive advantage can only be obtained if the company has the right competitive strategy. This means that company's strategy is an important part of company's organizational system that will play a role to improve business performance.

Some management strategy literature shows that suitability of strategy with resources is an important start to improve the company performance. Wernerfelt (1984) and Grant (2010:11) said that strategic resources owned and controlled by companies are used as the basis to formulate and implement strategies to realize optimal business performance. In addition, Barney (1991) emphasizes that continuity or excellence of a company depends on resources owned and strategies chosen to empower these resources to respond the strengths and weaknesses in their internal environment, as well as opportunities and challenges from their external environment. These concepts were proven by Slater et al. (2006); Sulastri (2006), and Muafi (2008). The research to supports the direct effect of competitive strategies on financial performance are Yamin et al. (1999), Fenney et al. (2005), Husnah (2013).

One effort to find the right strategy is SWOT analysis. SWOT analysis is a systematic identification of various factors to formulate a company's strategy. Peace and Robinson (2011: 197) determine right strategy through SWOT analysis based on assumption that effective strategies are derived from "conformity" between the company's internal resources (strengths and weaknesses) and their external situation (opportunities and threats). SWOT analysis can be applied to profit-oriented and non-profit organizations. Companies have ability to compete and determine the goals of business ventures and identifying the internal and external factors that profitable and not profitable to achieve these goals (Hill and Westbrook, 1997). Cole (2006) considers SWOT analysis as "a combined analysis of external and internal problems affecting organizational performance". Lynch (2006) believes 
this is "strengths and weaknesses analysis show internal strength within organization, coupled with Opportunities and Threats faced organization externally." Therefore, it was found that there was a significant relationship between strategy SWOT analysis and company performance (Alexander, 2000; Ogundele and Opeifa, 2004; Oluremi and Gbenga, 2011; Oginni, 2012; Babatunde and Adebisi, 2012; and Adeoye 2012).

One phenomenon created in health care companies in city of Palu, Central Sulawesi. Competition in this business is getting tougher with evidence that more and more clinics are opened by individuals and private hospitals owned by companies or foundations. In addition, community also demands services provided by health service providers. There is a tendency for people of Palu city to have middle to upper income level, preferring to private hospitals, with reason for quality of their services, compared to choice of government hospitals that have high human resources and adequate facilities and infrastructure. Anutapura Hospital has an outpatient service facility of 20 Polyclinics, 10 medical support installations, 5 non-medic supporting installations, and treatment room (550 beds, ICU and Triggers). Anutapura Hospital as the Public Service Agency (PSA) in health sector still has some disadvantages in community service. These are the patient service procedures that are still too long and low quality BPJS program services. This is indicated by complaints from patients of Anutapura General Hospital. The observations and secondary data show that BOR (Bed Occupancy Ratio) has decreased and functional income as the Regional Public Service Agency has decreased from 2015-2017 (source: Profile of General Hospital, Anutapura, 2017)

Observations results illustrate that hospital's performance has a problem in relation with hospital performance. One solution to deal this problem is to carry out a SWOT analysis as a basis to determine strategies to overcome the problem. Some studies on hospitals prove that strategies application can improve hospital performance (Griffith JR et al., 2002; Shaw C, 2003; Wu, Wei, 2014; Kalay \& Lynn, 2014; Ibnu Hajar, 2015; and Chang et al., 2017). Specifically, SWOT analysis can improve performance (Lee, Ha-yun, 2014) and Nwakoby et al, 2017)

Based on this background, this study focuses on problem of how to improve hospital performance based on the company's strategy, by observing the internal and external environment at Anutapura Hospital based on SWOT analysis.

\section{THEORITICAL REVIEW}

\section{Strategy}

Analysis results of company's internal and external environment are needed to create a strategic intent and develop a strategic mission (Hitt et al. 1997: 20-21). Strategic intent is the utilization of internal resources, capabilities and core potential of company to do what was originally considered a goal that cannot be achieved in a competitive environment. The strategic intent reflects what company can do as a result of its core competencies and unique ways used to build competitive advantage and getting sustainable profits above the average. A strategic mission comes from a strategic intent, a strategic intent application. Strategic missions provide a general description of products that must be produced and markets to support the use of their core potential. Once formulated, strategic intent and strategic mission form the basis to develop business strategies and corporate strategies. A business-level strategy emphasizes actions that must be taken to provide value to consumers and gain competitive advantage through the utilization of core competencies in market of a particular product.

David (2011: 18) defined strategy as a tool along with long-term goals to be achieved. Business strategies include geographical expansion, diversification, acquisition, product development, market penetration, tightening, divestment, liquidation, and joint ventures. The strategy emphasizes the importance of potential actions that require a large number of top management decisions and company resources. In addition, strategies affect the company's long-term development, usually for next five years. Therefore, strategies have future orientation. Strategies have multifunctional or multidivisional consequences and need to consider both external and internal factors faced by company.

\section{SWOT Analysis}

Rangkuti (2009: 20) defined SWOT analysis as a systematic identification of various factors to formulate a company's strategy. The analysis is based on logic to maximize strength, and opportunity, but simultaneously can minimize weaknesses and threats. Company performance can be determined by a combination of internal and external factors. These factors must be considered in SWOT analysis. SWOT stands for Internal Strengths and Weakness as well as external environments Opportunities and Threats faced in business world. The SWOT analyzes a systematic identification of various factors to formulate a hospital strategy. This analysis is based on relationships or interactions between internal elements on external elements. The steps are as follows:

\section{Identification of Internal and External factors}

This identification is needed to find the factors effecting the progress or development of a hospital.

\section{a. Internal factors}

Internal factors possessed by Anutapura General Hospital in Palu City which include strength and weakness factors which greatly affect the development of Anutapura Hospital in Palu City. 


\section{b. External factors}

External factors affect the development of Anutapura Hospital in Palu City which includes opportunities and threats.

The alternative strategies to develop hospital are below.

- SO (Strength-Opportunity) Strategy. This strategy uses the internal strength of Hospital to take advantage from external opportunities. The SO strategy is achieved by implementing the strategies of ST, WO, and WT. If the Hospital has a major weakness the Hospital will try to make these weaknesses become strengths. If the Hospital faces a major threat, Hospital will try to avoid threats if it concentrates on opportunities.

- WO (Weakness-Opportunity) Strategy. This strategy aims to improve internal weaknesses of hospitals by utilizing existing external opportunities. One alternative of WO strategy is with Hospital can recruit and train staff with required abilities and qualifications.

- ST (Strength-Treats) Strategy. This strategy is carried out by the strength of Hospital to avoid threats if the conditions allow or minimize the external threats. This external threat does not always have to be dealt with by Hospital itself, depending on threat problems faced, such as economic factors, government regulations, natural phenomena, and so forth.

- WT (Weakness-Treats) Strategy. This position is very difficult for Hospital, but it does not close the possibility for Hospital to overcome this difficult position. The hospital must minimize weaknesses or allows the Hospital to eliminate internal weaknesses and avoid existing external threats to achieve the objectives.

Interpretation of SWOT Analysis Results for Development

a) If the strength and opportunity factors are more dominant or greater than weaknesses and threats, Hospital can compete with existing competitors.

b) If the strength and opportunity factors are smaller than weakness and threat factors, Hospital must consolidate in to strengthen itself before competing with others.

\section{Hospital Performance}

Performance measurement is a process to evaluate the work progress towards predetermined goals and objectives. These include information on efficiency of resources usage to produce goods and services; quality of goods and services (how well goods and services are delivered to customers and the customer's satisfaction level); the results of activities are compared with intended purpose; and effectiveness of actions to achieve the goals (Robertson, 2002). The public sector performance measurement system is aimed to help public managers to assess the achievement of a strategy through financial and non-financial instruments. Performance measurement systems can be used as an organizational control tool, because performance measurement can be strengthened by reward and punishment systems (Mardiasmo, 2009: 121).

WHO (World Health Organization) defined hospitals as an integral part of health organizations and social organizations, which function to provide comprehensive health services, both in form of curative and preventive to wider community. Hospitals also become training center for health employees and health research center. Law of Indonesia Republic for hospital no. 44 of 2009, article 1 paragraph (1) stated that a hospital was a health service institution to organize individual health services in a comprehensive manner to provide inpatient, outpatient and emergency services.

Performance Measurements with Standard Measurement Methods for Health Services at Anutapura Regional General Hospital performance measurement still uses the standard measurement of national health services based on Health Act No. 23 year 1992. The performance measures are used as follows: 1) BOR (Bed Occupancy Ratio); 2) LOS (Length of Stay = Average length of time a patient treated); 3) TOI (Turn over Interval); 4) BTO (Bed Turn Over = Bed rotation rate); 5) NDR (Net Death Rate); 6) GDR (Gross Death Rate); 7) Number of outpatients; 8) Number of hospitalized patients. Furthermore, Hospital Performance can be measured by Balanced Scorecard. Researchers use Kaplan and Norton's (2000) Balanced Scorecard: Implementing the Strategy into Action, through measurement: 1) Financial Perspective and 2) Customer Perspective.

\section{RESEARCH METHODS}

This study collected secondary data from Anutapura Hospital Profile at Palu City for period 2013 to 2017, Profile of Palu City Health Office in 2017, and Palu City BPS data in 2017 Year. Primary data was obtained through observation; interviews with hospital directors, hospital planning and finance, and some hospital patients; and conducted a Focus Group Discussion (FGD) with structural officials, medical personnel and administrative staff at Anutapura Hospital, Palu. The time period of study was applied last 4 months, namely from February to June 2018. Research location was Anutapura Hospital at Palu City, Central Sulawesi, Indonesia. The data was analyzed by descriptive method to explain actual and real conditions and classify the data. SWOT analysis was used to answer the research objectives. 


\section{RESEARCH RESULTS}

The identification of SWOT Analysis of Anutapura Hospital at Palu City is internal and external factors below.

1. Identifying Internal Factors (Strengths and Weaknesses).

This stage is composed of strengths and weaknesses factors obtained from observations and interviews with respondents of Anutapura Hospital at Palu City as follows.

\section{a. Internal factors}

- Strengths

Based on observations and interviews, the strength factors possessed by community, Hospital and relevant government can be identified in table 1 .

Table 1. Internal Factors (Strength / S)

\begin{tabular}{|c|l|l|}
\hline No. & \multicolumn{1}{|c|}{$\begin{array}{c}\text { Internal } \\
\text { Factors }\end{array}$} & \multicolumn{1}{c|}{ Strength } \\
\hline 1. & HR & $\begin{array}{l}\text { Having Health Employees (Doctors, nurses and administrations) who have competence } \\
\text { in their fields }\end{array}$ \\
\hline 2. & Production & $\begin{array}{l}\text { Providing 550 Bed facilities, doctor and nurse services, and drugs that guarantee patient } \\
\text { satisfaction }\end{array}$ \\
\hline 3. & Technology & Having medical devices and standardized facilities under ISO certification \\
\hline 4. & Marketing & Providing promotions through seminars, websites and socialization. \\
\hline 5. & Facility & $\begin{array}{l}\text { Having complete outpatient services (20 polyclinics), 10 medical support installations, } \\
\text { and 5 non-medical support installations. }\end{array}$ \\
\hline 6. & Services & $\begin{array}{l}\text { Providing appropriate and fast handling in accordance with SOP "Excellent Service } \\
\text { Image" with "Smile and Friendly" Motto }\end{array}$ \\
\hline
\end{tabular}

\section{- Weakness of Internal Factors}

The weakness factor is shown in table 2.

Table 2. Internal factors (Weakness / W)

\begin{tabular}{|c|c|c|}
\hline No. & $\begin{array}{l}\text { Internal } \\
\text { Factors }\end{array}$ & Weakness \\
\hline 1. & HR & Limited specialist Doctors (Heart, Surgery) \\
\hline 2. & Production & Limited daily operations \\
\hline 3. & Facilities & $\begin{array}{l}\text { Weak improvements at inpatient facilities, medical support and non-medical facilities. } \\
\text { These relate with factors below. } \\
\text { - There is no standard room facility for ICU, NICU / PICU } \\
\text { - } \quad \text { Not optimal drainage tool (Toilet and sewerage) } \\
\text { - } \quad \text { Poor management of Corpse Room. } \\
\text { - Do not have a communal septic tank, } \\
\text { - There is no circulation network of fire fighting vehicles, especially for buildings at } \\
\text { middle of Hospital, and } \\
\text { - Limited parking area. }\end{array}$ \\
\hline 4. & Marketing & Domination of WOM promotion, and the insurance cannot be claimed at hospital \\
\hline 5. & Services & $\begin{array}{l}\text { Complaints from patients who do not get excellent service. For example, there is no } \\
\text { information to public about the entrance to emergency room, and emergency room for } \\
\text { birth; the length of time the patient waits for outpatient polyclinic, as well as the lack of } \\
\text { friendly and smiling service. }\end{array}$ \\
\hline
\end{tabular}

\section{Identifying External Factors (Opportunities and Threats).}

This stage is composed of factors including opportunities and threats obtained from results of observations and interviews at Hospital as follows.

\section{- Opportunities}

Opportunities are power that can be used to achieve the greatest and widest opportunity and continuity. The external opportunities are below. 
Table 3. External Factors (Opportunities / O)

\begin{tabular}{|c|l|l|}
\hline No. & External Factors & \multicolumn{1}{c|}{ Opportunities } \\
\hline 1. & Sociocultural & $\begin{array}{l}\text { Better education and income of community will have an impact on awareness to } \\
\text { the health. }\end{array}$ \\
\hline 2. & $\begin{array}{l}\text { Research and } \\
\text { Development (R \& } \\
\text { D) }\end{array}$ & $\begin{array}{l}\text { Increased from Class B Hospital to Class A Hospital, development opportunities } \\
\text { are vertical (e.g. VIP type inpatient services, ICCU, NICU / PICU room, and } \\
\text { operation room development), and development of special Heart and Eye } \\
\text { installations. }\end{array}$ \\
\hline 3. & Technology & $\begin{array}{l}\text { There are various diseases, need for patients to get excellent service, and } \\
\text { development of medical technology, has an impact to increase the number of } \\
\text { services. }\end{array}$ \\
\hline 4. & Work Culture & $\begin{array}{l}\text { Customers want to be served appropriately, quickly, correctly and kindly. } \\
\text { Fulfilling patient expectations will have an impact on loyalty and more number of } \\
\text { services. }\end{array}$ \\
\hline 5. & Economy & $\begin{array}{l}\text { There is an opportunity to increase revenue from PSA from development of } \\
\text { facilities and infrastructure as well as improving service excellence. }\end{array}$ \\
\hline
\end{tabular}

\section{- Threats}

Besides the opportunities of course there will also be a threat that must be anticipated, as shown in table 4 .

Table 4. External Factors (Threats / T)

\begin{tabular}{|c|l|l|}
\hline No. & \multicolumn{1}{|c|}{$\begin{array}{c}\text { External } \\
\text { Factors }\end{array}$} & \multicolumn{1}{c|}{ Threat } \\
\hline 1. & Competitor & $\begin{array}{l}\text { The existing hospitals in Palu City and two international-scale hospitals will be built, } \\
\text { specifically for private hospitals, faster in their services. }\end{array}$ \\
\hline 2. & Government & Reduced assistance from Government (Local and National Budget) \\
\hline 3. & Location & The area is narrower at hospital. \\
\hline
\end{tabular}

Based on identification results of strengths, weaknesses, opportunities and threats factors at Anutapura General Hospital at Palu, SWOT IFAS and SWOT EFAS matrices were analyzed below.

\section{Internal Factor Analysis Summary (IFAS) and External Factor Analysis Summary (EFAS)}

Based on results of identification of IFAS and EFAS of each indicator, results of factor calculations can be presented below.

\section{- IFAS SWOT Matrix}

Based on results of SWOT identification analysis, total scores in accordance with respective indicators can be presented in Table 5.

Table 5. SWOT Matrix Analysis (IFAS) of Anutapura General Hospital

\begin{tabular}{|c|l|c|c|c|}
\hline \multicolumn{2}{|c|}{ Internal Factors } & Weight & Rating & Weight x Rating \\
\hline \multicolumn{2}{|c|}{ Strength } & & & \\
\hline 1 & HR & 0.142 & 4.00 & 0.568 \\
\hline 2 & Production & 0.098 & 3.00 & 0.294 \\
\hline 3 & Technology & 0.089 & 3.00 & 0.267 \\
\hline 4 & Marketing & 0.097 & 3.00 & 0.291 \\
\hline 5 & Facilities & 0.067 & 2.00 & 0.134 \\
\hline 6 & Services & 0.136 & 4.00 & 0.544 \\
\hline \multicolumn{2}{|c|}{ Total Strengths } & 0,629 & 3.167 & 2.098 \\
\hline \multicolumn{2}{|c|}{} & & & \\
\hline (Weakness) & 0.053 & 4.00 & 0.212 \\
\hline 1 & HR & 0.073 & 3.00 & 0.219 \\
\hline 2 & Production & 0.084 & 3.00 & 0.252 \\
\hline 3 & Facility & 0.078 & 3.00 & 0.234 \\
\hline 4 & Marketing & 0.083 & 3.00 & 0.250 \\
\hline 5 & Services & 0,371 & 3.200 & 1.167 \\
\hline \multicolumn{2}{|c|}{ Total Weakness } & 1,000 & 3.183 & 3.265 \\
\hline \multicolumn{2}{|c|}{ Total IFAS Score } & & \\
\hline
\end{tabular}

Source: Primary data processed, May 2018

Table 5 shows that Anutapura Hospital Development Strategy at Palu City is based on identification of internal factors ('strengths and weaknesses). It indicates that total IFAS value is 3.265 contributed by strength score of 2.098 and weakness score of 1.167. The biggest strength indicator is HR, meaning that HR is needed, namely Health Employees (Doctors, nurses and administrations) who have competence in their fields to meet the health service needed by community. The contribution of next indicator of commitment to service, meaning service 
should appropriate and fast handling in accordance with SOP "Excellent Service Image" with "Smile and Friendly" Motto that can have an impact on satisfaction and increased community loyalty.

The first internal weakness factors to affect the success of Anutapura Hospital Development Strategy at Palu City are related to weakness of inpatient facilities, medical support and non-medical facilities below.

- $\quad$ There is no standard room facility for ICU, NICU / PICU

- Not optimal drainage tool (Toilet and sewerage)

- Poor management of Corpse Room.

- Do not have a communal septic tank,

- There is no circulation network of fire fighting vehicles, especially for buildings at middle of Hospital, and

- $\quad$ Limited parking area

The second weakness of internal factors at is long duration service for complaints from patients who do not get excellent service. For example, there is no information to public about the entrance to emergency room, and emergency room for birth; the length of time the patient waits for outpatient polyclinic, as well as the lack of friendly and smiling service.

Furthermore, to find a map of importance level (rating), IFAS factors can be presented in Figure 1. Strength Rating

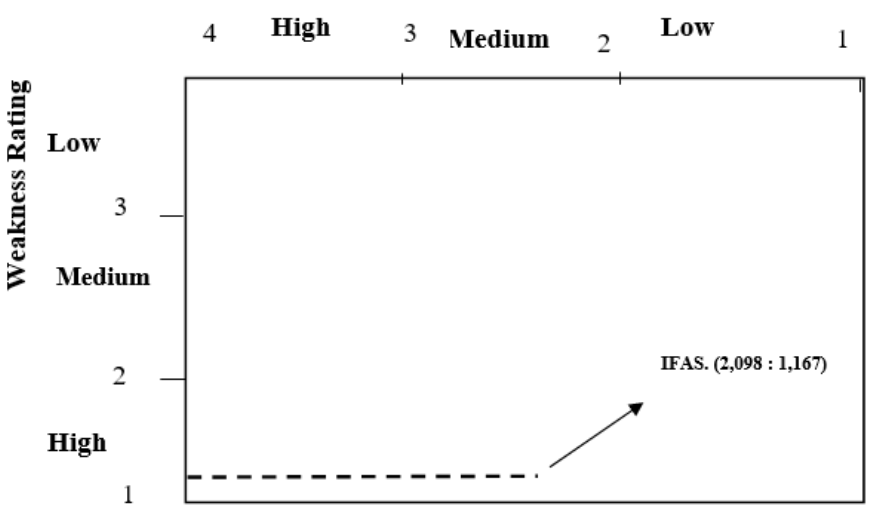

Figure 1. IFAS Position Map for Anutapura Hospital Development Strategy Source: Primary data processed, June 2018

Figure 1 shows that IFAS factors of Anutapura Hospital at Palu City have a medium strength rating and high weakness factor (Medium Vs High).

\section{- SWOT EFAS Matrix}

Based on results of SWOT identification analysis, total EFAS scores in accordance with respective indicators can be presented Table 6 .

Table 6. SWOT Matrix Analysis (EFAS)

\begin{tabular}{|c|c|c|c|c|}
\hline \multicolumn{2}{|r|}{ External Strategic Factors } & Weight & Rating & Weight x Rating \\
\hline \multicolumn{5}{|c|}{ Opportunities } \\
\hline 1 & Socioculture & 0.129 & 3.00 & 0.387 \\
\hline 2 & $\mathrm{R} \& \mathrm{D}$ & 0.142 & 4.00 & 0.568 \\
\hline 3 & Technology & 0.141 & 4.00 & 0.564 \\
\hline 4 & Work Culture & 0.092 & 2.00 & 0.184 \\
\hline 5 & Economy & 0.129 & 3.00 & 0.387 \\
\hline \multicolumn{2}{|r|}{ Total Opportunities } & 0.633 & 3.200 & 2.090 \\
\hline \multicolumn{5}{|c|}{ Threats } \\
\hline 1 & Competitor & 0.125 & 3.00 & 0.375 \\
\hline 2 & Government & 0.120 & 3.00 & 0.360 \\
\hline 3 & Location & 0.122 & 3.00 & 0.366 \\
\hline \multicolumn{2}{|r|}{ Total threats } & 0.367 & 3.000 & 1.101 \\
\hline & Total EFAS Score & 1.000 & 3.100 & 3.191 \\
\hline
\end{tabular}

Source: Primary data processed, May 2018

Table 6 shows that Anutapura Hospital at Palu City has total EFAS score of 3.191, contributed by opportunity score of 2.090 and threat score of 1.101. The largest opportunity indicator is Research and Development (R \& D), 
meaning that increase from Class B Hospital to Class A Hospital will provide a large opportunity for vertical development (e.g. VIP type inpatient services, ICCU room development, NICU / PICU, and operating room), and development of special Heart and Eye installations. Furthermore, second largest indicator is technology, meaning that with various diseases, patient's need to get excellent service, and development of medical technology to increase the number of services.

Threat factors that sufficiently affect on successful strategy of Anutapura Hospital with highest value are competitor indicator. It related to existing hospital competitors in Palu City and will be built 2 two international scale hospitals, specifically Private Hospitals with faster service. The second threat is related to development of facilities and infrastructure. The location of Anutapura Hospital is getting narrower. The next threat related to lower Local and Central Budget Grant every year.

The map of importance level (rating) of EFAS factors can be presented in figure 2.

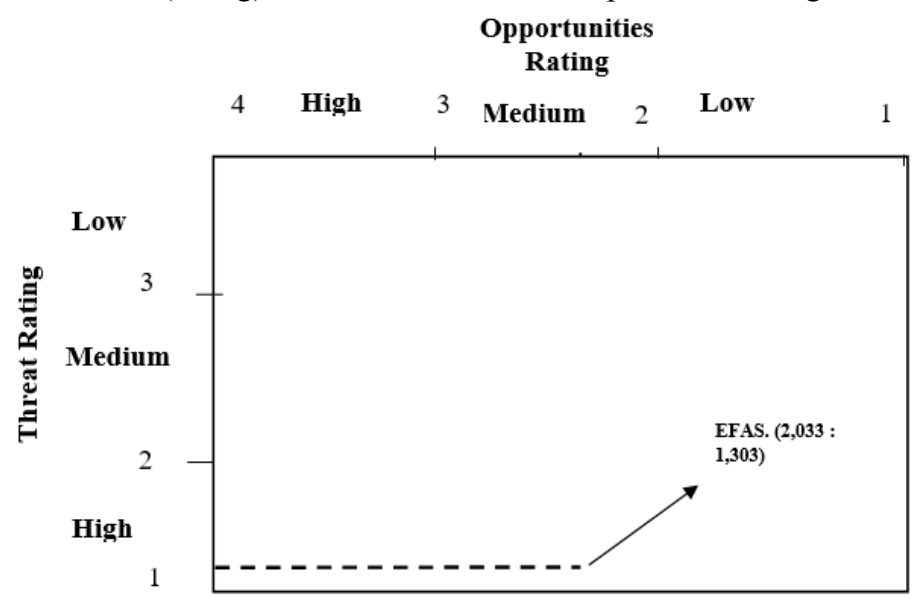

Figure 2. IFAS Position Map Based on Importance of Anutapura Hospital Development Strategy Source: Primary data reprocessed, June 2018

Figure 2 shows that EFAS factors at Anutapura Hospital has a moderate opportunity rating and high threat (Medium Vs High). Furthermore, to find the combined rating of IFAS and EFAS can be presented in figure 3.

\section{IFAS Rating}

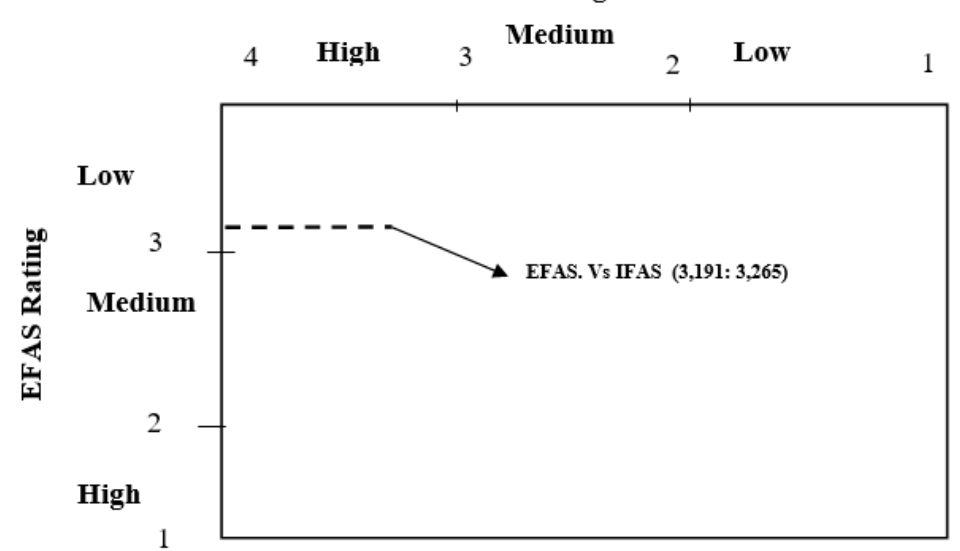

Figure 3. Map of Position of IFAS Vs EFAS Based on Importance of Anutapura Hospital Development

Source: Primary data processed, June 2018

Strategy

Figure 3 shows value of each IFAS and EFAS factor. It can be concluded that map position rating for IFAS factors (strength and weakness) in High area and for EFAS factors (Opportunities and Threats) in Low area.

\section{Anutapura Hospital Development Strategy}

Above calculations and matrices and position maps of each of factors become basis to compile the IFAS and EFAS matrix for Anutapura Hospital Development Strategy, as shown in table 7. 
Table 7. IFAS and EFAS Matrix of Anutapura Hospital Development Strategy

\begin{tabular}{|c|c|c|c|}
\hline IFAS & Strengths (S) & Weaknesses (W) \\
\hline $\begin{array}{c}\text { Opportunities } \\
\text { (O) }\end{array}$ & $2,098+2,090=4,188$ & $1,167+2,090=$ & 3,257 \\
\hline Strategy (SO) & Strategy (WT) \\
Threats (T) & $2,098+1,101=3,199$ & $1,167+1,101=2,268$ \\
\hline
\end{tabular}

Source: Primary data processed, May 2018

Table 7 shows that Anutapura Hospital Development Strategy is SO Strategy with a value of 4.188 and WO strategy with a value of 3.257 . This condition has a great strength to capture potential opportunities by trying to minimize future weaknesses.

\section{DISCUSSION}

Based on above SWOT analysis diagram, Anutapura Hospital Development Strategy can be formulated below. Quadrant 1 (SO):

It is a favourable situation with the power to take advantage of opportunities. The strategy that must be implemented is to improve HR competencies (doctors, nurses and administrations) through the research and development, utilization of renewable technology by increasing PSA income; encourage the production of hospital services through optimization of BOR utilization by increasing the work culture according to "Excellent Service Image" SOP with "Smile and Friendly" Motto in hospital environment; expanding the marketing network through verbal and non-verbal promotion approaches to community; and Optimizing outpatient care facilities (20 polyclinics), medical support installations (10 installations), and non-medical support installations (5 installations) through a work culture and socioculture approach and renewable technology usage.

\section{Quadrant 2 (ST):}

Despite various threats, these conditions still have high strength, but also need to minimize threats through following strategies: encouraging hospitals to increase HR competencies, increasing renewable technology, and socializing excellent services to anticipate competition from other hospitals; enhance collaboration with government to develop general health in hospitals through programmed and sustainable R \& D approaches; and strive for vertical development, utilizing the functions of old buildings and finding new land for long-term development, considering the need for higher health services sustainability and population increase, while the development area is getting narrower.

\section{Quadrant 3 (WO):}

Anutapura Hospital has a very large opportunity to develop A hospitals type. It need to implement strategies of income usage from PSA to improve HR competencies (especially cardiologists and surgeons) and improvement of medical and non-medical facilities and prescriptions; increase promotion and expand cooperation with other insurance; as well as improving service dissemination through a work culture approach to minimize complaints from Hospital customers.

\section{Quadrant 4 (WT):}

This situation is very unfavourable. The hospital faces weaknesses internally threats externally. The strategy is to encourage the improvement of human resources, especially cardiologists and surgeons, optimizing collaboration with government in assisting specialist medical education; optimizing marketing channels and socializing the prime service culture, in order to anticipate the threat of new competitors; and increasing land usage through improving medical and non-medical facilities and infrastructure. It is shown in figure 4. 


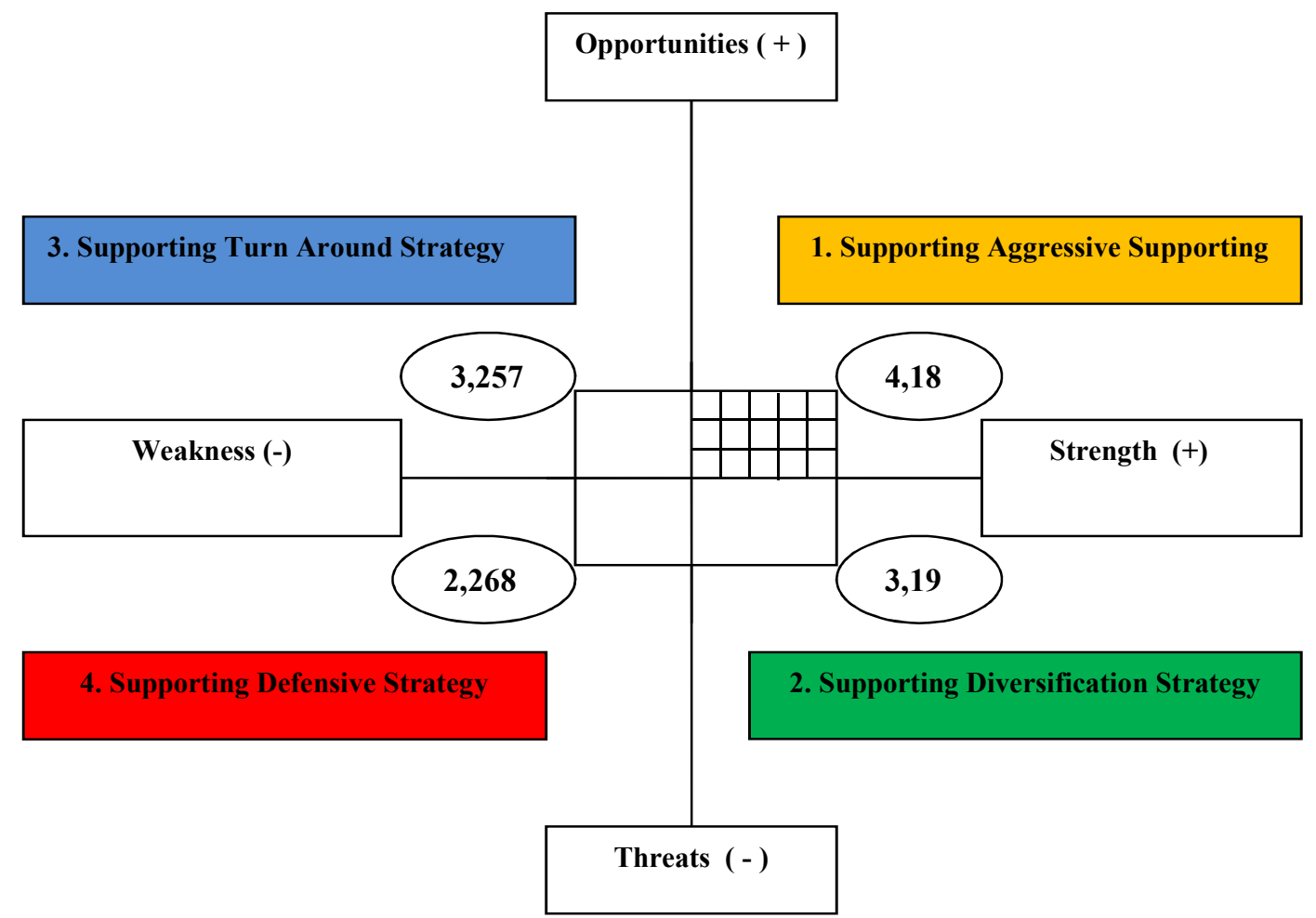

Figure 4. SWOT Analysis of IFAS and EFAS Matrix of Anutapura Hospital Development Strategy Source: Primary data processed, June 2018

Strategic issues and activities for Anutapura Hospital Development Strategy are based on highest SWOT score for strength and opportunity factors. Whereas for weakness and threat factors are taken from lowest score, as shown in table 8.

Table 8. SWOT Matrix of Anutapura Hospital Development Strategy

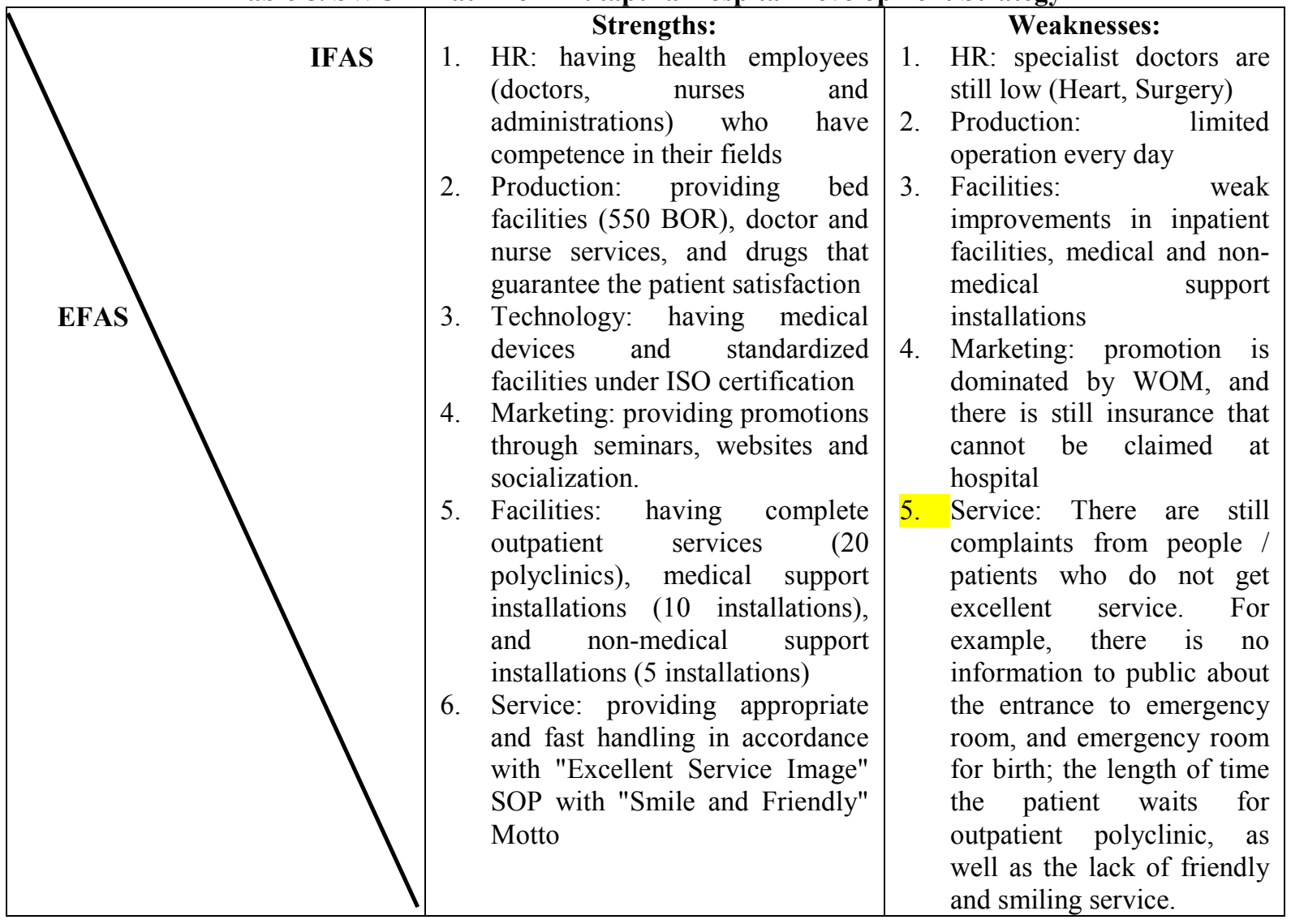




\section{Opportunities:}

1. Socioculture: better education and income of community will have an impact on awareness to the health.

2. Research and Development (R \& D): increased from Class B Hospital to Class A Hospital, development opportunities are vertical (e.g. VIP type inpatient services, ICCU, NICU / PICU room, and operation room development), and development of special Heart and Eye installations.

3. Technology: there are various diseases, need for patients to get excellent service, and development of medical technology, has an impact to increase the number of services.

4. Work Culture: customers want to be served appropriately, quickly, correctly and kindly. Fulfilling patient expectations will have an impact on loyalty and more number of services.

5. Economy: there is an opportunity to increase revenue from PSA from development of facilities and infrastructure as well as improving service excellence.

1. Competitor: the existing hospitals in Palu City and two international-scale hospitals will be built, specifically for private hospitals, faster in their services.

2. Government: reduced assistance from Government (Local and National Budget)

3. Location: the area is narrower at hospital.
SO STRATEGIES
1. Improving HR competencies (doctors, nurses and administrations) through the research and development, utilization of renewable technology by increasing PSA income

2. Encouraging the production of hospital services through optimization of BOR utilization by increasing the work culture according to "Excellent Service Image" SOP with "Smile and Friendly" Motto in hospital environment

3. Expanding the marketing network through verbal and nonverbal promotion approaches to community

4. Optimizing outpatient care facilities (20 polyclinics), medical support installations (10 installations), and non-medical support installations (5 installations) through a work culture and socioculture approach and renewable technology usage.

\section{WO STRATEGIES}

1. Utilizing PSA revenue to improve $\mathrm{HR}$ competencies

(especially

cardiologists and surgeons) and improvement of medical and nonmedical facilities and prescriptions

2. Improving promotion and expand cooperation with other insurance

3. Improving service dissemination through a work culture approach to minimize complaints from Hospital customers.

\section{ST STRATEGIES}

1. Encouraging hospitals to increase HR competencies, increasing renewable technology, and socializing excellent services to anticipate competition from other hospitals

2. Enhancing collaboration with government to develop general health in hospitals through programmed and sustainable $\mathrm{R} \&$ D approaches

3. Striving for vertical development, utilizing the functions of old buildings and finding new land for long-term development, considering the need for higher health services sustainability and population increase, while the development area is getting narrower.

\section{WT STRATEGIES}

1. Encouraging the improvement of human resources, especially cardiologists and surgeons, optimizing collaboration with government in assisting specialist medical education.

2. Optimizing marketing channels and socializing the prime service culture, in order to anticipate the threat of new competitors.

3. Increasing land usage through improving medical and non-medical facilities and infrastructure. 


\section{CONCLUSION}

The performance improvement of Anutapura Hospital at Palu City can be done with 4 strategies below.

\section{SO Strategies}

1. Improving HR competencies (doctors, nurses and administrations) through the research and development, utilization of renewable technology by increasing PSA income

2. Encouraging the production of hospital services through optimization of BOR utilization by increasing the work culture according to "Excellent Service Image" SOP with "Smile and Friendly" Motto in hospital environment

3. Expanding the marketing network through verbal and non-verbal promotion approaches to community

4. Optimizing outpatient care facilities ( 20 polyclinics), medical support installations (10 installations), and nonmedical support installations ( 5 installations) through a work culture and socioculture approach and renewable technology usage.

WO Strategies

1. Utilizing PSA revenue to improve HR competencies (especially cardiologists and surgeons) and improvement of medical and non-medical facilities and prescriptions

2. Improving promotion and expand cooperation with other insurance

3. Improving service dissemination through a work culture approach to minimize complaints from Hospital customers.

\section{ST Strategies}

1. Encouraging hospitals to increase HR competencies, increasing renewable technology, and socializing excellent services to anticipate competition from other hospitals

2. Enhancing collaboration with government to develop general health in hospitals through programmed and sustainable R \& D approaches

3. Striving for vertical development, utilizing the functions of old buildings and finding new land for long-term development, considering the need for higher health services sustainability and population increase, while the development area is getting narrower.

\section{WT Strategies}

1. Encouraging the improvement of human resources, especially cardiologists and surgeons, optimizing collaboration with government in assisting specialist medical education.

2. Optimizing marketing channels and socializing the prime service culture, in order to anticipate the threat of new competitors.

3. Increasing land usage through improving medical and non-medical facilities and infrastructure.

\section{RECOMMENDATION}

1. Anutapura Hospital has weaknesses related to HR, Production, Facilities, marketing and service. Strategies to overcome these weaknesses are to use all opportunities through WO strategy and Turn Down strategies.

2. Anutapura Hospital has threats related to competitors, government and location. Strategies to anticipate the threat are to optimize the strength of hospital through SO strategy and Diversification strategy.

3. Hospital has weaknesses and threats, it should namely minimize the weaknesses and avoiding threats (WT Strategy and Defensive strategies).

4. Anutapura Hospital Development Strategy at Palu City based on SWOT analysis is located in quadrant I to supports aggressive strategies or growth strategies. It is a position that strong, profitable and has many identified opportunities (SO). Anutapura Hospital can use these strategies to take advantage of opportunities based on their strengths.

\section{REFERENCE}

Adeoye, A.O. (2012). Impact of External Business Environment on Organizational Performance on Food and Beverage Industry in Nigeria. British Journal of Arts and Social Sciences, Vol. 6 No. 2, pp 56-65.

Alexander, D \& Britton, A. (2000). Financial Reporting. 5th edition. London: Thomas Learning Publishing. Armstrong. M. (2006) . A Handbook of Human Resource Management. Practice (10th edition)

Babatunde B. O. \& Adebisi A. O. (2012). Performance in a Competitive Business Environment. Economic Insights - Trends and Challenges LXIV (1)

Barney, J. (1991). Firm Resources and Sustained Competitive Advantange. Management Science, 17, 99-120.

Chang Chuan-Hui, Yu-Ching Chiao and Yafang Tsai. (2017). Identifying Competitive Strategies To Improve The Performance Of Hospitals In A Competitive Environment. BMC Health Services Research 17:756. Taiwan.

Cole, G.A. (2006). Strategic Management-Theory and Practice (2m1 Edition). London: Thomson Learning.

David, F.R. (2011). Strategic Management, $12^{\text {th }}$ ed Sunardi, D. (penerjemah). Manajemen Strategis. Konsep. Edisi 12, Buku 1. Jakarta: Salemba empat.

Data BPS Kota Palu Dalam Angka Tahun 2017 
Finney, R.Z \& Lueg, J.E. (2007). Market Pioneers, Late Movers, and the Resources-Based View (RBV): A Conceptual Model. Journal of Business Research, JBR-06526, 8.

Grant, R.M. (2010). Contemporary Strategy Analysis, $7^{\text {th }}$ Edition, John Wiley \& Sons, Ltd.

Griffith JR, Alexander JA, Jelinek RC. (2002). Measuring comparative hospital performance. J Health Manag. Jan-Feb;47(1):41-57

Hill, Terry and Westbrook, Roy, (1997). SWOT Analysis: it's time for a product recall from Long Range Planning. 30 (1) pp.46-52, Oxford: Pergamon.

Hitt, M.A., R.D., Ireland \& R.E., Hoskisson. (1997). Strategic Management: Competitiveness and globalization. Armand Adiyanto (penerjemah) Manajemen Strategis: Menyongsong era persaingan dan globalisasi. Jakarta: Erlangga.

Husnah. (2013). Competitive Strategy Role In Developing SMEs With RBV Perspective: A Literature Review. International Journal Of Business and Behavioral Sciences (Austria). ISSN: 2226-5651. March 2013. Volume 3 No. 3.

Ibnu Hajar. (2015). The Effect of Business Strategy on Innovation and Firm Performance in the Small Industrial Sector. The International Journal Of Engineering And Science (IJES). Volume 4 Issue 2 Pages 01-09. ISSN (e): 2319 - $1813 \operatorname{ISSN}(\mathrm{p}): 2319$ - 1805.

Kalay \& Lynn . (2014). The Impact Of Strategic Innovation Management Practices On Firm Innovation Performance. Research Journal of Business \& Management - RJBM, Vol.2 (3). PP 412 - 429.

Kaplan, Robert S. and David P. Norton. (2000). Balanced Scorecard: Menerapkan Strategi Menjadi Aksi. Erlangga: Jakarta.

Laporan Profil Rumah Sakit Umum Anutapura Kota Palu Periode 2013 - 2017.

Laporan Profil Dinas Kesehatan Kota Palu Tahun 2017.

Lee, Ha-yun. (2014). A SWOT analysis of the hospital performance management system in Hong Kong. Available at http://hdl.handle.net/10722/206979

Mardiasmo. (2009). Akuntansi Sektor Publik. Andi : Yogyakarta.

Muafi. (2008). Pengaruh Derajat Kesesuaian Orientasi Strategi, Lingkungan Eksternal,Struktur Saluran Ekspor, Budaya Organisasi dan Kinerja Ekspor. Jurnal Manajemen dan Kewirausahaan, 10 (2), 153-162.

Mulyadi. (2005). Sistem Manajemen Strategik Berbasis Balanced Scorecard. UPP AMP YKPN:Yogyakarta.

Nwakoby, Nkiru Peace, Raymond A. Ezejiofor and Ajike, Ada Kanu. (2017). Effect of SWOT Analysis on Performance of Manufacturing Firms in Nigeria. International Journal of Innovative Finance and Economics Research 5(4):40-51, Sept-Dec., 2017. ISSN: 2360-896X.

Oginni, B.O. (2012). The turbulent Business Environment in Nigeria, Somolu - Lagos Shecom Press Ltd.

Ogundele, O. J. K \& Opeifa, A. Z. (2004). The Influence of External Political Environment on the Processes of Entrepreneurship, the Nigerian Academic Forum: A Multidisciplinary Journal, Vol.7, No. 5, pp 7.

Oluremi, H.A., \&. Gbenga M.A. (2011). Environmental Factors and Entrepreneurship, Development in Nigeria, Journal of Sustainable Development in Africa Vol. 13, No. 4, pp 127- 139.

Panrell. J.A. (2006). Generic Strategies After Two Decades: A Reconceptualization of Competitive Strategy. Management Decision, 44 (8),1139-1154.

Peace II, J.A., Robinson J., \& Richard, B. (2011). Manajemenn Strategi - Formula, Implementasi, dan Pengendalian. Edisi 10, Buku 1. Jakarta: Salemba Empat.

Rangkuti, Fredy. (2009). Analisis SWOT Teknik Membedah Kasus Bisnis, cetakan kelimabelas, Penerbit : Gramedia Pustaka Utama, Jakarta.

Robertson, Gordon. (2002). Review Kinerja. Lokakarya Review Kinerja.BPKP dan Executive Education.

Shaw C. (2003). How can hospital performance be measured and monitored? Copenhagen, WHO Regional Office for Europe (Health Evidence Network report). Available at http://www.euro.who.int/document/e82975.pdf)

Slater, S.F., Olson, E.M., \& Hult, G.T. (2006). Research Notes And Commentaries The Moderating Influence Of Strategy Formation Capability - Performance Relationship. Strategic Management Journal, 27, 1221-1231.

Sulastri. (2006). Sebuah Pengembangan Model Hipotesis Pengaruh Aset Strategis dan Lingkungan Terhadap Pilihan Strategi Diversivikasi. Jurnal Manajemen \& Bisnis, 4 (7).

Undang-Undang Republik Indonesia No. 44 tahun 2009 Tentang Rumah Sakit .

Undang-Undang Kesehatan No 23 Tahun 1992 Tentang Metode Standar Pengukuran Jasa Pelayanan Kesehatan Pengukuran Kinerja Rumah Sakit Menggunakan Standar Pengukuran Jasa Pelayanan Kesehatan Nasional.

Yamin, S., Gunasekaran, A., \& Mavondo, F.T. (1999). Relationship between generic strategies, competitive advantage and organizational performance: an empirical analysis. Technovation, 19, 507-518.

Wernerfelt, B. (1984). A Resource-based view of the firm, Strategic Management Journal, 5, 171-180.

Wheelen, L.T., \& Hunger, J.D. (2001). Manajemen Strategis. Yogyakarta: Andi.

Wu, Wei, 2014. Hospital Competitive Strategies and Performance Outcomes. (PhD diss., University of Tennessee). Available at https://trace.tennessee.edu/utk_graddiss/2875. California. 